\title{
Anatomy of the Political Transformations during the Period of the Dissolution of the USSR on the Material from Kūhistoni Badakhshon
}

\author{
A. Kh. Daudov, V.A.Shorokhov, A.A.Andreev
}

For citation: Daudov A. Kh., Shorokhov V. A., Andreev A. A. Anatomy of the Political Transformations during the Period of the Dissolution of the USSR on the Material from Kühistoni Badakhshon. Vestnik of Saint Petersburg University. History, 2018, vol. 63, issue 3, pp. 799-822. https://doi.org/10.21638/11701/ spbu02.2018.309

The paper focuses on the anatomy of the ethno-political transformations of the unique administrative unit of the Tajik Soviet Socialist Republic during the late Perestroika period (1989-1991). The research object is the Kühistoni Badakhshon Autonomous Region (GBAO or simply the Pamirs). The subject being analyzed is the response to the massive crisis of the dissolution of the USSR by the exceptional sociopolitical system of the Soviet Pamirs. The core of the sources for the study was made up of documents and write-ups from the State archive of Kūhistoni Badakhshon Autonomous Region named after Kh. Buribekov (town of Khorugh, Tajikistan). These funds reflected the activities of main local political institutions, such as the Regional Soviet of the people's deputies, Executive Committee of GBAO, the Supreme Soviet of Tajikistan and its Presidium. The information from the national and regional press was also examined. On the basis of a wide range of sources it has become possible to reconstruct the features of administrative and social disorganization of the autonomous region as well as the key aspects in its search for new prospects. The "dissection" of the political transformations in the Pamirs in 1989-1991 enabled the scholars to conclude that the project of sovereignization of GBAO was unfeasible for many reasons, such as cultural antagonisms inside the region; discord among the "old" communist elites over the act "On GBAO" and declaration of the

Abdulla Kh. Daudov - Doctor in History, Professor, St. Petersburg State University, 7-9, Universitetskaya emb., St. Petersburg, 199034, Russian Federation; a.daudov@spbu.ru

Абдулла Хамидович Даудов - д-р ист. наук, проф., Санкт-Петербургский государственный университет, Российская Федерация, 199034, Санкт-Петербург, Университетская наб., 7-9; a.daudov@spbu.ru

Vladimir A. Shorokhov - PhD, Assistant, St. Petersburg State University, 7-9, Universitetskaya emb., St. Petersburg, 199034, Russian Federation; v.shorohov@spbu.ru, +79219723084.

Владимир Андреевич Шорохов - канд. ист. наук, ассистент, Санкт-Петербургский государственный университет, Российская Федерация, 199034, Санкт-Петербург, Университетская наб., 7-9; v.shorohov@spbu.ru

Artiom A. Andreev - PhD, Associate Professor, Department of Ethnopolitology, St. Petersburg State University. 7-9, Universitetskaya emb., St. Petersburg, 199034, Russian Federation; a.a.andreev@spbu.ru

Артем Алексеевич Андреев - канд. ист. наук, доц., Санкт-Петербургский государственный университет, Российская Федерация, 199034, Санкт-Петербург, Университетская наб., 7-9; a.a.andreev@ spbu.ru

This research was supported by the grant of the President of the Russian Federation for the young PhDs N MK-5515.2018.6 "Russia and Ethno-Political Processes in The Kūhistoni Badakhshon Autonomous Region of Tajikistan (1991-2005)"

(c) Санкт-Петербургский государственный университет, 2018 
republic; economic dependency on the Soviet centre; passiveness of the "ethnic Pamiri" in the republic administration of Tajikistan. The main external factors which should be emphasized were the influence of the conflict in Afghanistan and the absence of the support from "democratic" elite of the RSFSR.

Keywords: Kūhistoni Badakhshon, Late Soviet Period, Tajikistan, Ethno-Political History, Dissolution of the Soviet Union.

\section{Анатомия политических трансформаций эпохи распада СССР по материалам Горного Бадахшана}

\section{А. Х. Даудов, В. А. Шорохов, А. А. Андреев}

Для цитирования: Daudov A. Kh., Shorokhov V.A., Andreev A. A. Anatomy of the Political Transformations during the Period of the Dissolution of the USSR on the Material from Kühistoni Badakhshon // Вестник Санкт-Петербургского университета. История. 2018. Т. 63. Вып. 3. С. 799-822. https:// doi.org/10.21638/11701/spbu02.2018.309

В центре внимания статьи - анатомия политических процессов на уровне административной единицы Таджикской ССР в эпоху поздней перестройки (1989-1991 гг.). Объект исследования - Горно-Бадахшанская автономная область (ГБАО). Предмет исследования - реакция уникальной социально-политической системы советского Памира на масштабный политический и экономический кризис, сопровождавший распад СССР. Основу источниковой базы исследования составили документы и материалы Государственного архива Горно-Бадахшанской автономной области им. Х. Бурибекова (г. Хорог), отражающие деятельность ключевых властных структур региона - областного Совета народных депутатов и Исполнительного комитета Горно-Бадахшанской автономной области, а также Президиума Верховного Совета и Верховного Совета Таджикистана. Также были изучены материалы периодической печати республики и области на таджикском и русском языках. Большая часть привлекаемых источников вводится в научный оборот впервые. Использование широкой источниковой базы дало возможность детально и достоверно реконструировать картину кризиса административной системы автономии и основные направления поиска новых путей развития региона. Анализ системы политических процессов на Памире в 1989-1991 гг. позволил прийти к выводу о неосуществимости проекта суверенизации Горно-Бадахшанской автономной области по целому ряду причин. Среди таковых можно выделить: значительные противоречия между различными этнокультурными общностями региона; отсутствие единства представителей «старой» партийной номенклатуры в отношении как Закона «О Горно-Бадахшанской автономной области», так и провозглашения Автономной Республики Бахдашан (АРБ); экономическую зависимость от союзного центра; пассивность этнических памирцев, занимавших должности в центральных органах власти Таджикистана. Среди внешних фактов следует выделить «горячее дыхание» Афганистана и отсутствие поддержки со стороны «демократических» элит РСФСР. Визит в Таджикистан А.А.Собчака и Е.П.Велихова в сентябре 1991 г. показал, что российские тяжеловесы были готовы осуществлять посредничество лишь на общереспубликанском уровне взаимодействия политических сил. Провозглашению АРБ на фоне нарастающего гражданского противостояния мало кто придал существенное значение.

Ключевые слова: Горно-Бадахшанская автономная область, Таджикистан, позднесоветский период, этнополитическая история, распад СССР. 
The circumstances of the contemporary global politics connected with - if we apply mediaspeak - "the new Cold war" are often reminiscent of the events that took place in 1991. After all the years that have passed there is still not much agreement in the scholarly literature whether to evaluate the events as positive or negative. At the same time, it has to be noted that there is still a gap in the research body, which we will not refer to as "complex" since this adjective has been significantly overused in different research fields. Complexity (that is derived from Latin complexus, embraced or enveloped) does not mean focusing on the subject matter. It is, rather, a superficial analysis of it through the lens of several randomly chosen methodologies. It is probable that the very term was borrowed by social scientists from mathematicians.

In 1979, Maurice Mandelbaum, an American historian, adopted another term, this time from medicine - "anatomy". With the help of it, he explored the issue of objectivity of historical knowledge ${ }^{1}$. The method of opponency to causal understanding of history as a logical chain within this or that historical process that has a cause and effects acting as part of the whole, are quite applicable to research in the sphere of political transformations in the post-Soviet space. The understanding of historical process as a whole constituted by its form, character, effect and structure, i.e. not as a linear process but as an integrated system, its morphology, or "anatomy", offered by M. Mandelbaum, is of significant interest for our research, too.

The first attempt to implement the morphological analysis of historical process as a whole system was made in V. I. Bushkov's and D.I. Mikul'skiy's monography "Anatomy of civil war in Tajikistan"2. Such complex and non-linear phenomenon as that of civil war was analyzed there. The authors found a way, without, however, giving reasons for worthwhileness of the approach, to examine a yet unfinished conflict separately, in its different interpenetrating aspects, such as inter-ethnic relations, activities of secular and religious opposition movements, relations of authority and Central government office.

The authors of the present research have chosen a shorter, but nonetheless action-packed period for their analysis. The years of 1989-1991 were the time of geopolitical transformations in the post-Soviet space. It does not deem possible to fully analyze the morphology of systemic political transformations, roles of internal and external factors, as well as sociological, demographic and ethno-confessional aspects of the country's history within one article. That is why we are going to examine the anatomy of political processes at the level of one administrative unit of the Tajik SSR during the late perestroika. We are going to focus on Kūhistoni Badakhshon autonomous region (we'll employ Russified acronym GBAO because it is the most commonly used in Tajikistan). The research question here is the reaction of the regional social system to the large scale political and economic crisis that all the citizens of the USSR with no exception were faced with at the time.

The basic sources of this research are documents and materials from the State archive named after H. Buribekov in the town of Khorugh, GBAO. It is here that we enjoyed the opportunity to acquaint ourselves with rare documents on the most recent history of GBAO. Most of these sources are going to be introduced to scholarship for the first time.

Minutes and decisions of the sessions of regional Congress (Soviet) of People's Deputies of 1990-1991 (archive fund 1, inventory 49, cases 1-4), decrees of the Executive

${ }_{1}^{1}$ Mandelbaum M. H. The Anatomy of Historical Knowledge. Baltimore; London. 1979.

2 Bushkov V.I., Mikul'skii D. V. Anatomiia grazhdanskoi voiny v Tadzhikistane (etnosocial'nye processy i politicheskaia bor'ba, 1992-1995). M., 1996. 
committee of the regional Soviet of People's Deputies of 1989-1991 (archive fund 1, inventory 50, cases 1-6), and resolutions of the Supreme Soviet and the Presidium of the Supreme Soviet of Tajikistan (archive fund 1, inventory 48, cases 54-55) are of most value for this research. These primary sources allow to reconstruct, even if not in full, the big picture of the crisis of the administrative system of the autonomous territory and the main directions in search of its new ways of development.

To piece together the socio-political situation in GBAO and Tajikistan as a whole, the authors of this paper resorted to articles, interviews and informational materials in Russian and Tajik languages from the main periodical of the region "Badakhshoni Soveti" (Soviet Badakhshan) and some of the all-Soviet and national press, first of all, "Adabiyet va san'at" (Literature and Arts), "Vecherniy Dushanbe", "Kommunist Tajikistana", "Pamir", "Narodnaya gazeta" and "Komsomol'skaya Pravda".

The exceptional sensitivity of the subject matter as well as the absence of document compilations for the history of the first years of the country's independence predetermined the scarcity of the historiography of the research question. The items that are on the list are either of encyclopedic nature ${ }^{3}$ or research on other topics with brief insights into the recent history of Pamir ${ }^{4}$. It can be stated that the only author who purposefully studied the political processes in GBAO is M. M. Khudoerov ${ }^{5}$.

The significance and drama of the events of the civil war in Tajikistan have stimulated emergence of a number of works ${ }^{6}$, some of which, apart from the already mentioned Anatomy of the civil war in Tajikistan, seem to be objective research ${ }^{7}$.

Nowadays we understand the name Pamirs - in the physical, geographical sense as the huge quadrangular mountain range in the middle of Asia, in Tajikistan (GBAO occupies most of the Pamirs' territory - see fig. 1), China and Afghanistan. The whole territory is characterized by sharp continental climate, however, the peculiarities of the landscape provide for the differences between the West and East Pamirs. The latter, often referred to as Murghab, bearing the same name as the biggest river thereof, is a highmountain desert. In the west, numerous ridges are divided by deep and narrow valleys of the tributaries of the biggest river here, the Panj. It is this part of the mountain system that is historically called Badakhshan and populated by the Pamiris (mountain Tajiks), who differ in both their language and culture from other communities of Central Asia.

The Pamiris speak Eastern Iranian languages, and the majority of them follow Nizari Isma'ilism. According to the data of the Institute for humanities of the Tajikistan Academy of Science, there are nine separate languages and dialects that are classified as

3 Sharafieva O. H. Rol' regional'nyh klanov vo vnutrennei politike Tadzhikistana // Vestnik of Tomsk State University. 2012. Vol.359. P.98-100; Parshin P. B. Mesto i rol' Gorno-Badahshanskoi Avtonomnoi oblasti v Gosudarstvennoi sisteme Tadzhikistana // Mezhdunarodnaia analitika. 2016. Vol. 16, iss. 2. P. 8396.

${ }^{4}$ Rashid A. The Resurgence of Central Asia: Islam or Nationalism. London, 1994; Brasher R. Ethnic Brother or Artificial Namesake? The Construction of Tajik Identity in Afghanistan and Tajikistan // Berkeley Journal of Sociology. 2011. Vol.55. P.97-120; Malashenko A. V. Tadzhikistan: dolgoe eho grazhdanskoi voiny // Brifing Centra Karnegi. 2012. Vol.14, N 3.

${ }_{5}$ Hudoerov M. M.: 1) Problema Pamirskoi avtonomii v Tadzhikistane na rubezhe 1980-1990-h gg. // Vestnik of Chelyabinsk State University. Iss. 46. 2011. N 22 (237). P.78-81; 2) Social'no-politicheskie i etnokul'turnye transformacii na postsovetskom Pamire. Diss. ... kand. ist. nauk. Moscow, 2012.

${ }^{6}$ Rowland R.H. National and Regional Population Trends in Tajikistan: Results from the Recent Census // Eurasian Geography and Economics. 2005. Vol.46, N 3. P. 202-223.

7 Nourzhanov K., Bleuer K. Tajikistan: a Political and Social History. Canberra, 2013. 


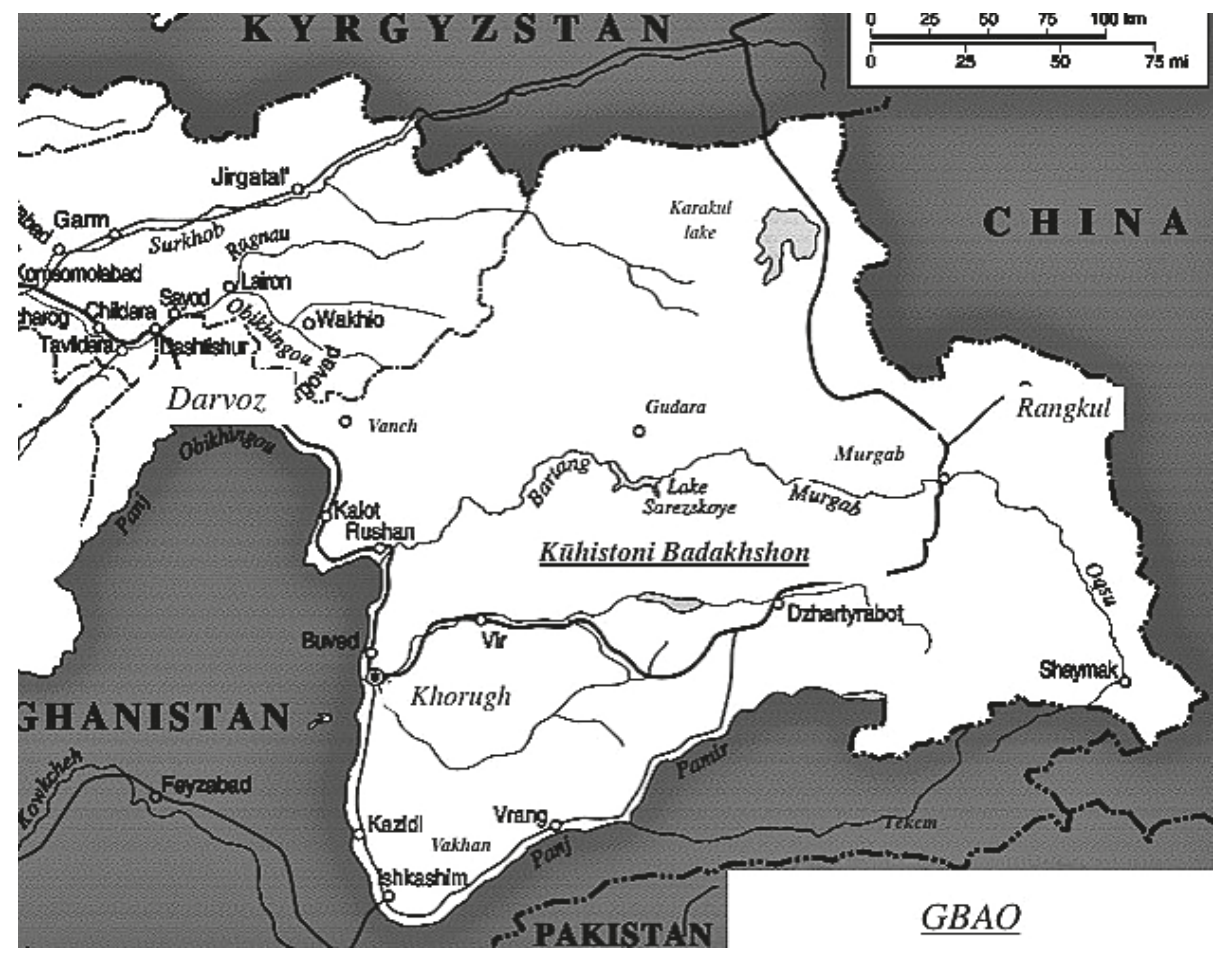

Fig. 1. Kūhistoni Badakhshon autonomous region of Tajikistan (1965-present)

"Old Iranian" languages 8 . The most numerous of the Pamir peoples live both in Tajikistan and Afghanistan (Shughnan, Wakhi, Rukhani peoples) ${ }^{9}$. Apart from them, there are local Farsi-speaking groups, some of whom associate themselves with the Pamiris, and some do not. There is a separate group of Yazgulam, at least 7000 people, who follow Sunni Islam but speak an Eastern Iranian language and consider themselves to be Pamiris. Therefore, most of the population of Badakhshan is a mixed range of people speaking Eastern Iranian languages, who have been gradually assimilated by the Tajiks ${ }^{10}$. There are also Turkicspeaking nomads living in the Minor and East Pamirs - the Kirghiz ${ }^{11}$.

${ }^{8}$ Honaliev N. GBAO - problemy social'no-ekonomicheskogo razvitiia // Central'naia Aziia i Kavkaz. 2004. Vol.31, iss. 1. P. 186.

${ }^{9}$ See: Pahalina T.N. Pamirskie iazyki. M., 1969. P.9-11; Osnovy iranskogo iazykoznaniia: sredneiranskie i novoiranskie iazyki. Moscow, 2008. P. 103-113.

${ }_{10}$ Monogarova L.F.: 1) Etnicheskii sostav i etnicheskie processy v Gorno-Badahshanskoi avtonomnoi oblasti Tadzhikskoi SSR // Strany i narody Vostoka. Iss.16. 1975. M., 1975. P.174-191; 2) Pamircy narodnosti il subetnosy tadzhikov? (otvet A. S. Davydovu) // Sovetskaia etnografiia. 1989. N 5. P.28-34; Bushkov V., Monogarova L. Etnicheskie processy v Gorno-Badahshanskoi avtonomnoi oblasti Tadzhikistana // Central'naja Aziia i Kavkaz. 2000. N 5. P.215-233 etc.

${ }_{11}$ Gvozdeckii N.A., Mihailov N.I. Fizicheskaia geografiia SSSR. Aziatskaia chast'. M., 1978. P. 146166; Arheologicheskaia karta Gorno-Badahshanskoi avtonomnoi oblasti. Zapadnyi Pamir (pamiatniki kamennogo veka -XX v.). Dushanbe, 2008. P.11-12. 
The geography of the Pamirs has a number of fundamental characteristics. Farming lands constituting only $13 \%$ of the western part of GBAO are a web of narrow river valleys that are part of the basin the Panj. The variation of altitudes has defined the co-existence of "several climatic zones that differ from hot subtropics in the lower part of the basin of the Panj to almost Arctic in its upper part"12. The prolific climate of Darvaz and Vanch (where even raising citrus cultures is possible ${ }^{13}$ along with their geographic position has made Darvaz "the Gates of the Pamirs", through which the influence of political entities of Transoxiana, Afghanistan and Iran was channeled, and which enjoyed the benefits of trading with them. That is why the pace of "Tajikization" of the north-west periphery of the Pamirs was higher, and Sunni Islam was quite firmly established in the region, having almost completely superseded Isma'ilism. The less fertile valleys of the rivers Gunt and Shakhdara were used more actively as passages to grazing lands and the road to Afghanistan and India. The Wakhan dictrict is characterized by peculiar features: first of all, the weather there is very severe, and, secondly, it was one of the points on the way of big migration from East Turkestan. In 1895, the Pamir Mountains became an object which great powers tried to divide. Most of it fell to the Russian empire lot (formally Khanate of Bukhara), lands to the right-hand shore of the Panj and the Minor Pamirs (Wakhan corridor) became part of Afghanistan, and Sarykol' was passed to the Qin China ${ }^{14}$.

The contemporary history of the Pamirs begins on 2, January, 1925 with a resolution of Central executive committee of the USSR to make GBAO part of the Tajik autonomous SSR ${ }^{15}$. When in 1929, Tajikistan became a Soviet republic "in its own right", the Pamirs had retained a special status ${ }^{16}$.

Despite the adherence of the government of the republic to the same assimilating policies during the post-war period, preconditions for the future "resurrection" of the Pamiri ethnic identity were created. This was primarily aided by the distinctness of the economic development of GBAO. With $80 \%$ per cent of funding subsidized by the republican centre, the local budget was consumed extremely irrationally, but still provided an increase in the highlanders' quality of life. The so-called "northern bonus" was in effect in the autonomous region. The constant presence of frontier guards in the villages of the narrow valley of the Panj provided for a significant number of workplaces. Given that, its inhabitants suffered very little from the process typical of republics of the USSR when they were forced to specialize in a certain field of agriculture or industry ${ }^{17}$. This is why outside GBAO the Pamiris lived mainly in Dushanbe. Their role in governmental structures in Tajikistan was insignificant, which reflected both their small number and a large number of citizens of Khujand in the said bodies.

12 Umarov H.U., Muhabbatov H.M., Akobirov Sh.Z. Piandzhskii transgranichnyi bassein: resursy i problemy social'no-ekonomicheskogo razvitiia // Izvestiia RAN. Ser. Geograficheskaia. 2014. Iss. 6. P. 101.

13 Arheologicheskaia karta... P. 41.

14 Postnikov A. V. Shvatka na "kryshe mira": politiki, razvedchiki i geografy v bor'be za Pamir v XIX veke (monografiia v dokumentah). M., 2001. P.296-341; Sergeev E. Ju. Bol’shaia igra, 1856-1907: mify i realii rossiisko-britanskih otnoshenii v Central'noi i Vostochnoi Azii. Moscow, 2012. P. 186-199.

15 Radzhabov S., Bobodzhanov N. Sovetskii Badahshan v bratskoi sem'e narodov SSSR. Dushanbe, 1975.

16 Ibid. P. 18-19.

17 Bozorov K.D. Pereselencheskaia politika pravitel'stva Respubliki Tadzhikistan v poslevoennyi period i ee social'no-ekonomicheskoe i kul'turno-bytovoe znachenie, 1946-1965 gg. Avtoref ... kand ist. nauk. Dushanbe, 2002. 
Therefore, the number, standard of living, levels of education and culture grew without having been propped up by either the corresponding pace of the agricultural development in the region or a significant role in ruling the republic. In essence, the territory, rich in natural resources, had no industrial site of nationwide importance. The assimilation pressure from the central powers of the TSSR further added up to this disproportion. In all-Soviet censuses, the Pamiris were never separated from Tajiks. Tajikization of education, literature, press and office work in GBAO suppressed even the position of the Russian language. The climax of this policy was the destruction of books in the Shughnan language in 1972 in the funds of Ferdowsi library in Dushanbe, which is mentioned by R. H. Dodihudoev ${ }^{18}$.

On the other hand, the significant input made by the USSR to the development of infrastructure inTajikistan surely had an effect on GBAO, too, where modern schools, hospitals, cultural centres, electric power plants, roads, airports were created, along with the system of free education. Literacy of the population of GBAO had grown from $2 \%$ in 1913 to almost $100 \%$ in 1984. The Pamirs were among the top of all of the Soviet Union regions in terms of the number of people with a university degree. The substantial improvements in the social sphere had led to changes and population explosion, and conduced to the mobility of people ${ }^{19}$.

The situation being what it was, the Pamiris adhered to the quite traditional ways of keeping to an identity. Accepting Tajik culture in its Soviet interpretation on the surface, they spoke their own languages with family and neighbours and practiced their own religions.

\section{The Situation in GBAO in the Context of the Collapse of the Soviet Union}

According to the census of 1989, 161000 people lived in GBAO, a disproportionally small ratio of the then 5 million inhabitants of Tajikistan given the size of the territory of the region ${ }^{20}$. The Pamirs were considered the most backward, in the socio-economic sense, part of Tajikistan and the USSR. The regional economics at that was in no small part subsidized straight from Moscow, just as the Far North regions in Russia were, and the main provision channel was still the Pamir road from the city of Osh, i.e. from Kirghizstan. The few mining enterprises that were there paid no taxes to the local government, and were managed from Dushanbe. Apart from that, the presence of a large number of Soviet troops from Central Asian and Eastern border military districts played a major role in the life of GBAO since they not only ensured the security of the region, but also were one of the main economic actors on the territory. We should not also forget that after the limited number of Soviet troops had been pulled out from Afghanistan, the warfare there was not finished but became even more intense. The glow of the fire that devoured more and more territories on the other side of the river, oftentimes had a significant influence on what was happening in GBAO.

${ }_{18}$ Dodihudoev R. H. Iazykovaia politika i iazykovoe stroitel'stvo v Tadzhikistane // Russkii iazyk v SSSR. 1991. N 9. P. 5-7.

19 Nijozov S. Shiity-ismaility Central'noi Azii // Central'naia Aziia i Kavkaz. 2003. Vol.30, iss. 6. URL: http://www.ca-c.org/journal/2003/journal_rus/cac-06/05.niyru.shtml (accessed 28.05.2018).

${ }^{20}$ Boldyrev V.A. Itogi perepisi naseleniia SSSR. M., 1990. P. 19. 
The situation described above may at first glance seem so chaotic that it would be difficult to define, in the chaos, primary and secondary processes, main events and their by-products, and main actors. Nevertheless, we are going to try to bring the matters together and outline a hierarchy of factors that had the biggest say in the development of the situation.

The key process that defined the development of events at the local level was the disintegration of the USSR followed by the establishment of sovereignty of Soviet republics. Despite the seeming instability of socio-economic base in Tajikistan, it was all the same part of the current. For the purposes of the discussion we may put the sovereignization of the republic into the time frame between 22, July, 1989, when the law "On language" was adopted $^{21}$, and 9, September, 1991, when the resolution of the Supreme Soviet of the Tajikistan "On the proclamation of State sovereignty of the Republic of Tajikistan" was made ${ }^{22}$.

This routine process of establishing a nation state (in the context of the time, of course) by Tajiks led to negative consequences that are often pointed out in historical works. To begin with, it was the liquidation of a unified economic territory, wherein the Central Asian republics were recipients of numerous benefits ${ }^{23}$. Secondly, there was mass fleeing of the population, Russian-speaking, first of all, from the republic ${ }^{24}$. But the third outcome, the actualization of the problems of autonomous regions, is of paramount interest to us.

The last issue was one of the most delicate in the relationships between the all-Union institutes of power and elites of the republics, both elites of the Party and "new democratic" ones.

Russian ethnologist S. V. Cheshko singled out two types of political nationalism, according to the position of this or that nation in the USSR and Post-Soviet society. The first group encompassed "nationalisms" of ethno-nations of Soviet republics that aim at creating and strengthening the privileged position for themselves and, correspondingly, at suppressing the population of another ethnic background. The priority for this type of nationalism was to achieve maximum independence from the Central office, preferably at the same time retaining economic benefits from cooperation with it. The clear external feature of such nationalism is more or less obvious "anticolonial", that is, anti-Russian government, and often just anti-Russian ideology. The other type of nationalism was characteristic of societies that were autonomies within the Soviet republics. Due to the discrimination from their republican "big brothers", they counted on the help from Soviet authorities, Russia and Russians. The main demand from the national leaders of autonomous territories was improvement of their status to the point of making them Soviet republics rather than autonomous regions, or their integration with the Russian Federation $^{25}$. In no small part, these hopes coincided with the framework of thought of the Soviet bureaucrats. In the spring of 1990, the Supreme Soviet set its sights on autonomization,

${ }^{21}$ Daudov A.H., Ovsiannikov D. V., Hasanov A. R., Ianchenko D. G. Problema transformacii statusa nacional'nyh iazykov narodov SSSR na primere sovetskogo i postsovetskogo Tadzhikistana v 1980-2010-e gg. // Obshhestvo. Sreda. Razvitie. 2015. N 4. P.91-99.

${ }^{22}$ Mezhdunarodnye otnosheniia v Central'noi Azii: Sobytiia i dokumenty. M., 2011. P.218-220.

${ }^{23}$ Pribaltika i Sredniaia Aziia v sostave Rossiiskoi imperii i SSSR: mify sovremennyh uchebnikov postsovetskih stran i real'nost' social'no-ekonomicheskih podschetov. M., 2009. P. 175-178.

${ }^{24}$ Sitnjanskii G.Ju. Rossiia i Central'naja Aziia: vmeste ili vroz'? Mezhetnicheskie otnosheniia v Srednei Azii i Kazahstane i Rossiia. M., 2011. P. 121-122.

${ }^{25}$ Cheshko S. V. Raspad Sovetskogo Soiuza. Etnopoliticheskii analiz. $2^{\text {nd }}$ ed. Moscow, 2000. P. 257-258. 
having adopted laws for unification of the status of Soviet and autonomous republics and making them federate. The failure of the project in the summer of the same year led to, as a matter of fact, the win of dominant ethnic groups ${ }^{26}$. As was duly - in our point of view noted by M.M. Khudoerov, the national movement of the Pamiris developed exactly in accordance with the second scenario ${ }^{27}$.

\section{Soviet of People's Deputies}

As much as we can judge from the materials of the regional archive of GBAO and the press, from January 1990 through December 1991, the main political activity of the population in the region, including any dialogue with Dushanbe, attempts to solve particular problems of the autonomy and development of reform projects took place in the local Soviet of People's deputies.

This body had held six sessions over the course of two years, one of which (the fourth) was not documented in the archives that we can access. Apart from that, the presidium of the Soviet was active: it prepared agenda for the sessions and communicated with the republican institutes. This evidence is further supported by the fact that the presidium made 113 resolutions, while the Soviet of people's deputies made only $98^{28}$. Apart from the 80 people's deputies, up to 130 representatives from the regional and smaller local administrations, power-wielding agencies, enterprises and public organizations took part in the sessions ${ }^{29}$. According to a note sent to the State Construction Committee of the TSSR, during the first year and a half of their functioning (that is, 5 sessions) the Soviet of GBAO dealt with 98 issues, most important of which were published in the "Badakhshoni Soveti" newspaper 15 to 20 days prior to the corresponding session in order to be discussed by the public ${ }^{30}$.

The analysis of the entry list of the Soviet of GBAO is a question worth a separate article. Nevertheless, now we can point out a number of most active people's deputies, who later on played an important role in the history of the Gorno-Badakhshan and Tajikistan as a whole. First of all, it was Darvaz Tajik A.I.Iskandarov, the Vanch's district people's deputy, elected as the Chairman.

Being at the same time Deputy Chairman of the Supreme Soviet of Tajikistan, he was in the 1990-1991 a conductor of the Pamirs' interests in Dushanbe. However, starting in autumn of 1991 it was exactly the reaching out to the opposition that will define, to a large extent, the fate of the Pamirs in the coming civil war. Apart from that, it is necessary to point out the future chairman of the Soviet, a Shughnani G. Sh. Shakhbozov. We would

26 Shahrai S. M. Mify i fakty o raspade Soiuza SSR // Raspad SSSR. Dokumenty i fakty (1986-1992 gg.). In 2 vols. Vol. II. Arhivnye dokumenty i materialy / ed. by S. M. Shahrai. Moscow, 2016. P.39-40.

${ }^{27}$ Hudoerov M. M. Social'no-politicheskie i etnokul'turnye transformacii ...P. 47-48.

${ }^{28}$ Zapiska o rabote Sovetov narodnykh deputatov Gorno-Badahshanskoi avtonomnoi oblasti, Rushanskogo, Shugnanskogo raionov po uluchsheniiu sessionnoi deiatel'nosti i povysheniiu aktivnosti deputatov // Gosudarstvennij arkhiv GBAO (further - GA GBAO). F. 1. Op. 48. D. 55. L. 23.

${ }^{29}$ Ruihati deputathoi Soveti deputathoi halkii VABK davati bistu jakum // GA GBAO. F. 1. Op. 49. D. 1. L. 45-46; Ruihati davatshavandagon ba sessijai dujumi Soveti deputathoi halkii VABK // Ibid. D. 2. L. 115-118; Ruihati davatshavandagon ba sessijai gajrinavbatii Shuroi deputathoi halkii VMKB // Ibid. D. 5. L. 25-27 etc.

${ }^{30}$ Saidov A., Safarov A., Azimov H. Zapiska o rabote Soveta narodnykh deputatov Gorno-Badahshanskoi avtonomnoi oblasti, Rushanskogo, Shugnanskogo raionov po uluchsheniiu sessionnoi deiatel'nosti i povysheniiu aktivnosti deputatov // GA GBAO. F. 1. Op. 48. D. 55. L.23. 
also like to note the fact that the number of Russian-speaking population in GBAO was meager, and the representatives thereof - people's deputies E. V.Turgunov and A.S. Afanasev were ordinary party functionaries.

Therefore, in our opinion, the Soviet Badakhshan within the time frame of perestroika obtained a typical self-government system that was there in order to solve the problems that local people were actually concerned with. There had accumulated quite a number of such problems at the time.

\section{Projects and Day-to-Day Realities of Late Soviet Regional Economics}

By the summer of 1989, crisis of transport infrastructure and the supply system of the region had arisen simultaneously. It was largely connected to the catastrophes that wrought havoc upon the region - the repercussions of the earthquake in Hisor, and landslides ${ }^{31}$.

In the spring, as far as we can judge by the indirect data from our sources, the only motor road that connected the region with Dushanbe was not functioning ${ }^{32}$. From June through August 1989, there was irregular water provision for enterprises in Khorugh, which, in its turn, led to problems in bread supply to the biggest town in the region ${ }^{33}$. At the same time, the flight connection of the regional capital with Dushanbe was paralyzed, and that caused disorders in Khorugh airport ${ }^{34}$. The situation largely repeated itself in 1990 - subsidies to recovery works alone after another earthquake were worth 8000000 roubles $^{35}$. Needless to say, significant development projects in the troubled region could be all but forgotten about.

It was obvious that no big scale aid could be received from the national authorities. In this situation, however, people's deputies of GBAO managed to initiate, 'over the head' of Dushanbe, a decision at top level of the USSR.

On 26, July, 1990, there came a resolution of the Council of Ministers of the USSR "On certain measures for socio-economic development of GBAO in the Tajik SSR in 1991-1995”. It stipulated the overall development in the region and gave instructions to corresponding ministries for the practical implementation of the program. For instance, Ministry of Energy of the USSR was allocated the task of finishing the construction of hydro-electric power station Pamir-1 and to commence construction of hydro-electric power station Pamir-2; Ministry of Industry was to finance a pharmaceutical plant in Khorugh that was supposed to produce 5 million medicine bottles and 250 million medicine containers per year ${ }^{36}$. Given that, some of the archival documents suggest that in August 1990 the implementation of at least some of these measures were re-allocated

31 Sovet narodnykh deputatov Gorno-Badahshanskoi avtonomnoi oblasti, Ispolnitel'nyi komitet: Rasporiazhenie N 92-r ot 25 iiulja 1989 g. // GA GBAO. F. 1. Op. 50. D. 2. L. 224.

32 Sovet narodnykh deputatov Gorno-Badahshanskoi avtonomnoi oblasti, Ispolnitel'nyi komitet: Rasporiazhenie N 50-r ot 10 maia 1989 g. // GA GBAO. F. 1. Op. 50. D. 1. L. 55.

33 Osnovanie desiatoi sessii Soveta narodnykh deputatov GBAO dvadcatogo sozyva ot 15 sentiabria 1989 g. // GA GBAO. F. 1. Op. 43. D.30. L. 77.

34 Sovet narodnykh deputatov Gorno-Badahshanskoi avtonomnoi oblasti, Ispolnitel'nyi komitet: Rasporiazhenie N 82-r ot 5 iiulia 1989 g. // GA GBAO. F. 1. Op. 50. D.1. L. 1.

35 Sovet narodnykh deputatov Gorno-Badahshanskoi avtonomnoi oblasti, Ispolnitel'nyi komitet: Rasporiazhenie N 68-r ot 5 iiulja 1990 g. // GA GBAO. F. 1. Op. 50. D. 3. L.2-4.

36 Postanovlenie Soveta Ministrov SSSR ot 26 iiulia 1990 goda o nekotoryh merah po social'noekonomicheskomu razvitiiu Gorno-Badahshanskoi Avtonomnoi Oblasti Tadzhikskoi SSR v 1991-1995 goda // Badahshoni Soveti. 1990. 11 avg. P. 4. 
to the Council of Ministers of Tajikistan. The latter evidently attempted to re-analyze the scale of the project, according to their "actual capabilities", and "taking into account that from 1, January, 1991, the tasks will have to be completed under the conditions of market economy, self-government and self-financing" 37 . An important factor was the adoption of the "Declaration of national sovereignty of the TSSR" 38 on 24 August, which put in question the very possibility of the central government of the USSR to make decisions on socio-economic development of the regions in the republic. Eventually, only the finishing of construction of Pamir-1 was accomplished.

\section{Afghanistan's "hot breath"}

The official pullout of Soviet troops from Afghanistan that was finished on 15, February, 1989, made the situation on the borders much more complicated. According to the data published by V.V. Tereshchenko, in 1990 alone, 113 conflicts were registered ${ }^{39}$ on the Soviet-Afghani borders, even though active hostilities in the areas of Afghanistan that bordered GBAO had not taken place for a long while. Nevertheless, the documents from the regional archive demonstrate that the situation was far from peaceful.

The materials of the fifth session of the Soviet of people's deputies that took place on 12 and 13, April, 1991, characterize the situation on the borders in most detail. The border issues were discussed there with the Head of the $66^{\text {th }}$ (Khorugh) KGB border detachment of the USSR V.M. Rogov, Head of the KGB department of GBAO A.L.Edelev, Deputy Head of Department of Internal affairs of GBAO A. Mamadnazarov and Procurator of GBAO S.D.Dzhumaev. As we can see from the minutes of the meeting and the attachments thereof, the most pressing problem for the border guards were regular armed conflicts with Afghani and Tajik groups of smugglers, consisting of 10 to 15 people, who primarily smuggled drugs, or course, , and systematic pressure from the drug cartel on the border guards and local bureaucrats. Heads of regional power-wielding agencies informed the people's deputies of the Afghani mujahiddin's purposeful activity to create an armed "anti-Soviet underground opposition" with an Islam-based political program on the territory of GBAO, referred to by A.L.Edelev as "Project-M". The success of the sabotage was to a large extent aided by weakening control of the border, lax punishment for border violation, progressing lack of qualified personnel in the autonomous region, and absence of a developed cargo screening system (for instance, Khorugh airport had been lacking in equipment since 1973) ${ }^{40}$.

In the summer of 1991 in Badakhshan Province of Afghanistan, neighboring Panj, high intensity conflicts broke out between the troops of M. Nadzhibulla and Afghani mujahiddin. An unexpected indirect consequence of these conflicts was the bombing of the

37 Protokol N IH-31 (I-I) soveshhaniia u predsedatelia Soveta Ministrov Tadzhikskoi SSR t. Hajoeva I.H. // GA GBAO. F. 1. Op. 48. D. 54. L. 65.

38 Deklaraciia o gosudarstvennom suverenitete Tadzhikskoi Sovetskoi Socialisticheskoi Respubliki (proekt); Postanovlenie Prezidiuma Verkhovnogo Soveta Tadzhikskoi SSR N94 ot 13 avgusta 1990 g. o proekte Deklaracii o gosudarstvennom suverenitete Tadzhikskoi Sovetskoi Socialisticheskoi Respubliki // GA GBAO. F. 1. Op. 48. D. 54. L. 7-8.

39 Tereshhenko V. V. Samaia effektivnaia okruzhnaia pogranichnaia sistema (1960-1990 gg.) // Vestnik of Tomsk State University. Gumanitarnye nauki. Istoriia i politologiia. 2013. Vol. 121, N 5. P.233.

${ }^{40}$ Protokol N 5 sessijai panchum (davati bistujakumi) Shuroi deputathoi halki vilojati muhtori Kuhistoni Badahshon // GA GBAO. F. 1. Op. 49. D. 4. L. 24-28, 106-124. 
kishlak (village) Namadguti Poyen in Tajik Wakhan, by an Afghanistan Air Force aircraft, which resulted in four people killed and nine injured ${ }^{41}$.

Despite the official apologies made by M.Nadzhibulla and the government of the neighboring country, the tragic incident brought up an unprecedented - for the Pamirs question of creation of air defense. This led to the Supreme Soviet of Tajikistan asking the Ministry of Defense of the USSR, upon the initiative of the Chairman of the Soviet of GBAO A.Iskandarov, to "solve the issue of deploying air defense forces on the territory of the republic". The date of the inquiry is 10 September ${ }^{42}$. By then, Ishkashim, Wakhan and Shughnan districts of the Afghani Badakhshan had already been under control of Akhmad shakh Mas'ud for a month ${ }^{43}$. Despite the assurance of good intentions made by the new neighbours, there was no doubt that soon the situation there would aggravate.

The negative influence of Afghanistan could be easily seen in the economics of GBAO, too. Even before the Soviet troops, however limited, were pulled out, the autonompos region regularly sent substantial amounts of humanitarian aid to the border areas of Afghanistan's Badakhshan ${ }^{44}$. After the troops had been pulled out, the humanitarian aid continued to be delivered, despite the worsening of the economic situation in the whole of the Pamirs. For instance, a resolution by the Executive committee of 19, October, 1989, stipulated non-repayable shipment from warehouses in GBAO of 40 tons of chemical fertilizers, 2 tractors, 50 tons of cement, and many other items and materials that the region largely lacked ${ }^{45}$. The assistance plan, "handed down" by Cabinet of Ministers of the USSR, stated that help be provided by GBAO in 1990 to the "other side of the river" to the equivalent of one million and a half roubles ${ }^{46}$. Judging by the documents of the regional Executive committee, there were also extra shipments, primarily of those products that were acutely needed in the Soviet Pamirs (such as flour, equipment for hospitals, farming machinery), especially if we take into account the worsening isolation, and the crisis of the communal infrastructure. Apart from that, groups of Afghani refugees regularly crossed the border entering GBAO, and the expenses for their alimentation and housing were covered by the region's budget to ${ }^{47}$.

${ }^{41}$ Rahmonkulov R., Shoinbodov N. Foч̨ia dar Namadgut (tafsili vokea) // Badahshoni Soveti. 1991. 6 iiulia. P. 1.

42 Postanovlenie Verkhovnogo Soveta Respubliki Tadzhkistan N 405 ot 10 sentiabria 1991 g. O zaprose narodnogo deputata Respubliki Tadzhikistan Iskandarova A. ot Vanchskogo izbiratel'nogo okruga N 224 "Ob obespechenii bezopasnosti naselenija Gorno-Badahshanskoi avtonomnoj oblasti i ukreplenii ee granic" // GA GBAO. F. 1. Op. 48. D. 55. L.21.

${ }^{43}$ Babahanov U. Na granice s Afganistanom // Tadzhiki idut (stat'i, reportazhi, interv'iu). Dushanbe, 2012. P. 72; Akimbekov S. M. Istoriia Afganistana. Astana, 2015. P. 384.

${ }^{44}$ Sovet narodnykh deputatov Gorno-Badahshanskoi avtonomnoi oblasti, Ispolnitel'nyi komitet: Rasporiazhenie N 9-r ot 31 ianvaria 1989 g. // GA GBAO. F.1. Op. 50. D. 1. L. 142.

45 Sovet narodnykh deputatov Gorno-Badahshanskoi avtonomnoi oblasti, Ispolnitel'nyi komitet: Rasporiazhenie N 146-r ot 19 oktiabria 1989 g. // GA GBAO. F. 1. Op. 50. D. 2. L. 42-43.

46 Sovet narodnykh deputatov Gorno-Badahshanskoi avtonomnoi oblasti, Ispolnitel'nyi komitet: Rasporiazhenie N63-r ot 10 maia 1990 g. // GA GBAO. F. 1. Op. 50. D. 3. L. 86; Sovet narodnykh deputatov Gorno-Badahshanskoi avtonomnoi oblasti, Ispolnitel'nyi komitet: Rasporiazhenie N 60-r ot 7 maia 1990 g. // Ibid. D.2. L. 110; Sovet narodnykh deputatov Gorno-Badahshanskoi avtonomnoi oblasti, Ispolnitel'nyi komitet: Rasporiazhenie N59-r ot 4 maia 1990 g. // Ibid. L. 113 etc.

47 Sovet narodnykh deputatov Gorno-Badahshanskoi avtonomnoi oblasti, Ispolnitel'nyi komitet: Rasporiazhenie N 128-r ot 19 sentiabria 1989 g. // GA GBAO. F.1. Op. 50. D.2. L.33; Babahanov U.Na granice... P.72. 
As can be seen from the above, the documents from the regional archive and the press in GBAO show quite a detailed picture of the negative influence from the southern neighbor of autonomous region.

\section{The Murghab Problem}

If we generalize and say that the Pamirs were the most backward and remote region of Tajikistan, then Murghab district of the autonomy had always been "GBAO within GBAO". Whilst occupying 60, $7 \%$ of the area of Soviet Pamirs, it was the least populated area of the region (12 700 people) ${ }^{48}$. The climate in Murghab was often considered very harsh. The ridges of the East Pamirs are surrounded primarily by flat desert plains, at the altitude of 3200-4000 meters above sea level. In these high-mountain deserts, where Arctic winter is followed by cold summer, agriculture is impossible. That is why since long ago Murghab has been populated by nomads. The evidence of their presence is scattered everywhere there, both in burial mounds and petroglyphs. Since the 16 century, the Khirgiz have come to the fore and they are still the main population of this district of the Pamirs. An important feature of Murghab has always been stable transport connection with the Osh region in neighbouring Kirghizstan, that is, Ferghana Valley. It is from here that the Russian Empire began annexation of the Pamir Mountains in the 1890s. This unique combination of national peculiarities and the extreme natural conditions predestined a permanent catastrophic socio-economic state of Murghab. According to the documents of the Executive committee of the Soviet of GBAO, already in 1989 appropriation of any funds took no less than a year, and in the healthcare institutions there was a shortage of even Analgin (pain-reliever) (and there was not a single pharmacy in the district) ${ }^{49}$. Apart from that, as the self-government mechanisms, within the framework of the people's deputies system, were gradually introduced, the language barrier was becoming a more and more pressing problem, and the problem interfered with Murghab deputies taking part in the functioning of the new democratic institutions. As we can see from the documents, the major part of the discussions in the Soviet of GBAO was held in the Tajik language, which, apparently, was not taught in the primarily Turkic-speaking region. This problem was often discussed during the sessions of people's deputies ${ }^{50}$. Since the beginning of 1990, the disintegration of the Soviet Union started to take its toll on the situation in Murghab. For example, the economic situation was worsening even faster. Due to the transition from cash to cheques in providing loans, the number of private homes built had decreased three times. The provision of agriculture products for the locals was achieved largely by sending food items from more well-off Kalai-Khumb and Vanch districts of the region ${ }^{51}$. More than that, as the sovereignization of the Soviet republics progressed, the issue of the grazing lands that

48 Vsesoiuznaia perepis' naseleniia 1989 g. Chislennost' naseleniia soiuznykh respublik SSSR i ih territorial'nykh edinits po polu // Demoskop Weekly. URL: http://www.demoscope.ru/weekly/ssp/sng89_ reg1.php (accessed 15.04.2018).

49 Vystuplenie predsedatelia ispolkoma Murgabskogo raionnogo Soveta narodnykh deputatov t. Polushkina A.A. na IX sessii oblastnogo Soveta narodnykh deputatov // GA GBAO. F. 1. Op. 43. D. 29. L. 6-10.

50 Protokol N5 sessijai panchum (davati bistujakumi) Shuroi deputathoi halki vilojati muhtori Kuhistoni Badahshon L. 20-21.

${ }^{51}$ Protokol N3 sessijai panchum (davati bistujakumi) Shuroi deputathoi halki vilojati muhtori Kuhistoni Badahshon // GA GBAO. F. 1. Op. 43. D. 3. L. 6-7. 
were gratuitously lent to GBAO in the Alai district of Kirghizstan became more thorny. The pasture lease, where 14789 of beef cattle, 38670 of small ruminants, and 500 horses grazed, was to be terminated on 1, January, $1991^{52}$.

The events in Osh in June 1991 became a good marker of the acuteness of the "Murghab problem".

At the time of conflicts in the Ferghana valley, a group of 90 young people from a kishlak (village) of Karakol attempted to ride to the north in order to support the Kirghiz people there. They were stopped by the border control ${ }^{53}$. In the centre of district, Murghab kishlak, there was an attack on Uzbek people sent to GBAO on a government assignment. The attack was initiated - or strongly supported - by an official from the local department of culture M. Murzakulov. The attack was soon stopped due to the interference of $\mathrm{KGB}^{54}$.

Apart from the problem of inter-ethnic relationships, the conflict in Osh also raised the question of cargo transport security on the main road of GBAO, the Pamir highroad, which, according to the report by a people's deputy B. Tashtanbekov at the September session of the Soviet, had been blocked for some time ${ }^{55}$.

So, as we can see, by 1991, a range of issues in Murghab further and systematically complicated the already difficult situation in GBAO.

\section{The fight for the resurrection of the Pamir languages and legislative draft "On GBAO"}

The eighth chapter of the Constitution of the TSSR of 1978 provided for adoption, by the Supreme Soviet and on the initiative of the regional People's Deputies Soviet, a law on $\mathrm{GBAO}^{56}$. However, the development of the legislation draft was stalled. Meanwhile, since 1988, behind the Khaburabot Pass debates about the "national resurrection" had been in full swing, involving some of the Badakhshani humanitarian intelligentsia supported by a number of influential Russian scholars. In the press, writers and scholars criticized equating Tajiks to the Pamiris, as well as the economic policies of the Tajikistan and the authorities of GBAO, which did not aid the development of mining industry in the region. Voices were also raised for the revival of the print culture by means of developing alphabets for spoken languages of Badakhshan ${ }^{57}$.

In 1990, cultural activism of the Pamiris in the capital acquired also a religious layer. On the initiative of a Pamir, Khudoiberdi Kholiknazarov, PhD in history, a society called

52 Iskandarov A. I. Zapiska o nekotorykh voprosah social'no-ekonomicheskogo razvitiia Murgabskogo raiona Gorno-Badahshanskoi avtonomnoi oblasti // GA GBAO. F. 1. Op. 48. D. 54. L. 46.

${ }^{53}$ Protokol N5 sessijai panchum (davati bistujakumi) Shuroi deputathoi halki vilojati muhtori Kuhistoni Badahshon. L.28.

54 Druzhba vsego sil'nei // Badahshoni Soveti. 1991. 19 iiunia. P. 4.

55 Protokol N3 sessijai panchum (davati bistujakumi) Shuroi deputathoi halki vilojati muhtori Kuhistoni Badahshon. L.7.

${ }^{56}$ Konstitucija (Osnovnoj Zakon) Tadzhikskoi Sovetskoi socialisticheskoi Respubliki. Dushanbe, 1987. P. 12 .

57 Cheshko S. V. Vremia stirat' belye piatna // Sovetskaia etnografiia. 1988. Iss. 6. P.5-6; Davydov A. S. Ne obosnovanno... zato publicistichno // Sovetskaia etnografiia. 1989. Iss. 5. P.15-23; Grjunberg A.L., Steblin-Kamenskij I. M. Neskol'ko zamechanii po povodu otklika A.S. Davydova na stat'iu S. V. Cheshko // Sovetskaia etnografiia. P. 35-38; Dodihudoev R. Dokole budem slyt' mankurtami // Kommunist Tadzhikistana. 1989. Iss. 5. P. 28-29; Zurobekov N. Shoh jo gado // Adabiet va san'at. 1989. 10 avg. P.3. 
Nosiri Khusrav was created. Members of the society saw their role in enlightening the Isma'ilis of the TSSR. They advocated creating houses of worship in Dushanbe and other localities where the Nizaris lived, supporting and reviving their religious customs, raising children in the traditions of the faith of their ancestors, publishing and distributing corresponding literature ${ }^{58}$.

The pressure of the public, difficult economic situation and an apparent possibility of extending rights of the region in the context of systematic liberation of relationships between centres and periphery were an original impulse that induced the governmental structures of the region to turn to the problem of the status of the Pamir languages. This was probably the first step taken in order to see the reaction of officials in Dushanbe, along with the local and capital public.

In January 1989 the regional committee of the Communist Party of Tajikistan organized a debate "Language and development of culture" in Khorugh. Party functionaries, officials from the educational system, and employees of the Department of Culture discussed the necessity to include the Pamir languages into the school curriculum. There were only 3 members out of 21 participants, who expressed an explicitly negative attitude to the matter. The rest formulated their own understanding of the problem of implementation regional languages, native to most of its population, into the study process ${ }^{59}$.

After the adoption of the republican law "On language" on 22, July, 1989, linguistic aspirations of the Pamiris were made legal. The third chapter of the law stated that "Tajik SSR creates conditions for unhindered development and usage of mountain Badakhshan (Pamir) languages and preservation of Yagnobi language. The Gorno-Badakhshan region is given the right to autonomously decide on the issues of how the local languages should function" 60 . It is probable that in striving to quickly bring certainty to the sensitive question, the TSSR Cabinet made a regulation on 17 July (i.e., before the law was adopted) on "Measures for implementation of Tajikistan's Law on Language", in which, among other things, the Executive Committee of GBAO was charged with developing measures in order to aid functioning and conservation of the Pamir languages, as well as proposals that are to be discussed at the republican level ${ }^{61}$. In order for these legislations to be executed, the Executive committee of the Soviet of People's deputies of GBAO formed a committee that included heads of local administrations, scholars and representatives from each of the language communities. There were three groups in the committee. The first one was charged with the task of creating an alphabet, the second was to implement the Pamir languages on the television, in businesses and institutions and in the sphere of culture, and the third one was to develop better measures aimed at teaching Tajik language to local people $^{62}$.

As a matter of fact, in 1989, conditions to solve the language problem were created. But the situation with the adoption of the law "On GBAO" was much more difficult. Judging by the minutes of the sessions of the Soviet, the first discussions of the law started on 4, September, 1990. Dissatisfaction of people's deputies and representatives of the public

${ }^{58}$ Hudoerov M. M. Social'no-politicheskie i etnokul'turnye transformacii... P. 136.

59 Ibid. P. 102-103.

60 Zakon Respubliki Tadzhikistan ot 22 iiulja 1989 goda N 150 “O iazyke”. URL: http://online.zakon. kz/Document/?doc_id=30496905 pos=0;38 (accessed 10.04.2018).

${ }_{61}$ Postanovlenie Soveta Ministrov Tadzhikskoj SSR "O meropriiatijah po vypolneniiu Zakona Tadzhikskoj SSR o iazyke” // Vechernii Dushanbe. 1989. 17 iiulia, N 136 (5276). P.2.

${ }^{62}$ Hudoerov M. M. Social'no-politicheskie i etnokul'turnye transformaci... P. 103-107. 
with the "spinelessness" of the legislative draft offered can be easily noted ${ }^{63}$. They were opposed, for example, to the absence of mentioning, let alone defining, of the status of the Pamir languages, and the absence of a chapter on prohibition to change the borders of autonomous region without the consent from the regional government. Deputies also suggested that the number of representatives of GBAO in Supreme Soviet of the TSSR should be increased to 12 , and an office for a permanent representative of the region in the TSSR Cabinet should be made. As an option, such representative could be Deputy Head of central government at the same time.

A speech by the member of Executive committee, Sh. Kokulov, was especially radical: for instance, he proposed legislating nonpartisanship of court, prosecution, Executive Committee and staff of trade unions, and also implementing dual subordination of the Executive committee, both to republican ministries and to the regional Soviet of People's deputies.

However, most of the suggestions were much more reasonable and aimed at correcting and clarifying the document. Following the results the discussion, the project was passed in its first reading ${ }^{64}$.

\section{1}

The beginning of the last year of the existence of the USSR was dramatic for the Pamir region.

In January, the autonomous region suffered yet another earthquake. As we already stated, the situation at the border was rapidly deteriorating; the same was true for the matters of supplies and crime. Hopes to realize the regulations of the Cabinet of the USSR in the conditions of disintegration of the state formation disappeared along with the snow. At the same time, aspirations that connected the bright future of the region with advancement of its political status grew. During the first ten days of April, the Presidium of the Soviet of People's Deputies of GBAO prepared and published a constitutional project "On GBAO" in the local newspaper "Soviet Badakhshan"65. The draft, which consisted of seven chapters (95 parts), was to include the region into the late-Soviet political system under the terms that were quite ordinary for the time. For instance, finally the features of the region, which formed the basis for granting autonomous status, were officially recognized: "GBAO is the type of Soviet autonomy that was defined on the basis of common territory, geographical conditions, co-existence of Tajik (Persian), Yazgulyam, Rushan, Bartang, Shughnan, Wakhan, Rhin languages, economic and spiritual singularity, and adjacency to other states". Referring to the Constitutions of both the USSR and the TSSR, and in view of the historical association, GBAO was considered part of the Tajik SSR. The Tajik language retained its exclusive official status, but the project allowed for use of the Pamir languages in court, which meant their inclusion into the legal environment. There was no

${ }^{63}$ Protokol N3 sessijai panchum (davati bistujakumi) Shuroi deputathoi halki vilojati muhtori Kuhistoni Badahshon. L. 14-25.

${ }^{64}$ Karori Soveti deputathoi halkii vilojati avtonomii Badahshoni Kuhii RSS Tochikiston N 38 az 2 sentjabri soli 1990 // GA GBAO. F. 1. Op. 49. D. 3. L. 44.

${ }^{65}$ Konuni chumhurii shuravii socialistii Tochikiston dar borai Vilojati Muhtori Kuhistoni Badahshon (loiha) // Badahshoni Soveti. 1991. 6 apr. P. 1-3; Konuni chumhurii shuravii socialistii Tochikiston dar borai Vilojati Muhtori Kuhistoni Badahshon (loiha) // Badahshoni Soveti. 1991. 9 aprelia. P. 1-3. 
direct statement that there were communities other than Tajik in the autonomy, as well as no mentioning of the religious diversity of a significant part of the Pamir Mountains. It is obvious that mentioning Isma'ilism and accepting the right of the Pamiris to self-identification would have brought up the question of the status of Tajik-speaking population of Darvaz and Vanch, and the Kirghiz of Murghab.

The provision for control over the natural resources of the region by its own administration was consequential, and concordant with the spirit of the time. Still, we cannot agree with the understanding offered by M.M. Khudoerov that this was the most important part of the law ${ }^{66}$. Unlike the romantics in the literary circles of Dushanbe, people's deputies were bound to understand that the very geographic position of the region and the state of infrastructure wouldn't allow its entering the world market of crude materials in the near future. Judging by the documents of the work of the Soviet of the region, this provision could rather have, apart from the populist, particular and applicable significance, ensuring the development of the local laws on nature conservation, and tourism control ${ }^{67}$.

The law "On GBAO" reformed the representation system of the region at the level of the USSR. Five people's deputies were to be delegated to the Congress of People's Deputies of the USSR. Two people from the region were to represent the autonomy in the Soviet of Nationalities of the Supreme Soviet.

In our opinion, the most important fact was that GBAO was granted the right to leave TSSR and USSR freely, provided that an all-region referendum was held. The day of the creation of GBAO, 2 January, was proposed as a regional holiday.

It is evident from the minutes of the April session of the regional Soviet of People's deputies, that there was no consolidated understanding of the project in the local political circles. A whole range of elected officials tried to make minor amendments to the legislation, probably thinking that its development could be continued. First Secretary of the regional Committee of the Communist Party of Tajikistan S. Beknazarov during the discussion of the project of law commented that it was of premature nature since constitutional changes at the level of Tajikistan and USSR were bound to come, and it was on the basis of these changes that a legislative act on GBAO should be developed. In contrast, the representative of Rushan, U.M.Aksakolov, insisted that the law project be passed to the Supreme Soviet of the TSSR as soon as possible. The majority of the participants of the session evidently shared his opinion, and the act was passed ${ }^{68}$.

While the discussion of the prospects of changes in the status was taking place, the local authorities tried to initiate works for reconstruction of the regional infrastructure that suffered from the earthquake in January. According to the ordinance №42 of the Cabinet of Ministers of the TSSR of 15, April, 1991, the Executive committee of the Soviet of People's deputies of GBAO ordered to allocate an additional 25, 3 million roubles of capital investments in 1991. It was planned to spend this sum on "financing the reconstruction

${ }^{66}$ Hudoerov M. M. Social'no-politicheskie i etnokul'turnye transformacii... P. 54.

67 Karori Soveti deputathoi halkii vilojati avtonomii Badahshoni Kuhii RSS Tochikiston N 44 az 4 sentjabri soli 1990 // GA GBAO. F.1. Op. 49. D.3. L. 50; Polozhenie ob ohote i vedenii ohotnich'ego hoziaistva na territorii GBAO // Ibid. L. 51-63; Protokol N 5 sessijai panchum (davati bistujakumi) Shuroi deputathoi halki vilojati muhtori Kuhistoni Badahshon. L. 2 etc.

${ }^{68}$ Protokol N 5 sessijai panchum (davati bistujakumi) Shuroi deputathoi halki vilojati muhtori Kuhistoni Badahshon. L. 22-24. 
of damaged industrial and non-industrial objects and construction of new ones in lieu of the destroyed ones"69.

Part of the reconstruction cost was to be made up for by the local enterprises, "Tajikpromstroybank", "Tajikagroprombank" and "Tajikbankbusiness", although most of the expenses were to be met by the still existing Centre. The office for industrial and commercial sector and general public services of the Executive committee of GBAO and the Consumers' association of GBAO were ordered to allocate tasks and to conclude delivery agreements for extra goods and materials which were assigned to GBAO by the Ministry of Trade of the USSR in 1991.

It was especially noted that consumer goods and building materials would be available for sale to inhabitants, and shop fixtures and fittings would be used to equip educational, trade and catering objects, and distributed upon approval by the Executive committee of $\mathrm{GBAO}^{70}$. All in all, according to the data of the Supreme Soviet of the TSSR, during the first half of 1991 the Centre had allocated 46 million roubles for liquidating the consequences of the catastrophe. In fact, though, due to the progressing disintegration of the channels of distribution system, only 12 million were appropriated ${ }^{71}$.

Perhaps, this is why the Cabinet of Ministers of the Tajik SSR ordered 1.5 thousand tons of meat, 1 thousand tons of butter and 1 thousand tons of sugar to be transferred to the disposal of the Executive Committee of GBAO from the reserve of the Government of the USSR to meet the needs of the population affected by the earthquake ${ }^{72}$.

Unfortunately, in the documents that we were able to access there was no detailed description of what the damage suffered by the autonomy from the earthquake was. However, other sources suggest, for instance, that the theatre in Khorugh was destroyed by $\mathrm{it}^{73}$.

Generally, the archival documents and the press enable to make a conclusion that by the middle of 1991, the socio-economic situation had acquired a range of new recessionary features: cutbacks on cropland acreage (in overpopulated, agrarian Pamirs!), debt crisis, and a decrease in construction by $1 / 3^{74}$. Another precursor of the social disruption was the increase in unemployment rates (up to 6200 people capable of working) ${ }^{75}$. The region was on the brink of an upsurge of protests.

Despite all the difficulties, it is barely germane to talk about separatist, anti-Soviet or even anti-communist sentiments of most population in GBAO. The all-Soviet referendum on the future of the USSR held in March 1991 clearly demonstrated the attitudes of the people of GBAO towards the existing political situation: out of 78383 people that took part in the referendum, 77246 voted for the political continuation of the Soviet Union ${ }^{76}$.

${ }^{69}$ Sovet narodnykh deputatov Gorno-Badahshanskoi avtonomnoi oblasti, Ispolnitel'nyi komitet: Rasporiazhenie N 24-r ot 23 aprelia 1991 g. // GA GBAO. F. 1. Op. 50. D. 5. L. 89.

70 GA GBAO. F.1. Op. 50. D.5.. L. 90.

71 Saidov A., Safarov A., Azimov H. Zapiska o rabote Soveta narodnykh deputatov GornoBadahshanskoi avtonomnoi oblasti, Rushanskogo, Shugnanskogo rajonov po uluchsheniiu sessionnoi dejatel'nosti i povysheniiu aktivnosti deputatov // GA GBAO. F. 1. Op. 48. D. 55. L. 23.

72 Sovet narodnykh deputatov Gorno-Badahshanskoi avtonomnoi oblasti, Ispolnitel'nyi komitet: Rasporiazhenie N 24-r ot 23 aprelia 1991 g. L. 90.

73 Chetvertyi teatral'nyii festival' v Tadzhikistane // Teatr. 1991. Iss. 10. P. 48.

${ }^{74}$ Gulhandaev Sh. O chem govoriat itogi polugodiia // Badahshoni Soveti. 1991. 26 iiulia. P. 4.

75 Zapiska o rabote Sovetov narodnykh deputatov Gorno-Badahshanskoi avtonomnoi oblasti, Rushanskogo, Shugnanskogo raionov po uluchsheniiu sessionnoi dejatel'nosti i povysheniiu aktivnosti deputatov. L. 23.

76 Baroi Ittihodi navshuda ovoz dodand // Badahshoni Soveti. 1991. 20 marta. P. 1. 
Nevertheless, there are no grounds to state that the Badakhshan people didn't have any ambitions to change. First of all, as it was often the case on the post-Soviet Union territory, a swift "resurrection" of the religious constituent of national identity of the Pamirs came about. The most telling of the markers of this process were the first contacts since the 1930s of religious leaders (Pirs) of Shughnan and Darvaz with none other than Aga Khan IV, and a visit of his high-ranking representatives M. Kashevdzhi, A. Radzhput and S. Dzhalol, to GBAO on 27 June - 6 July 1991. An important consolidating pretext for the Nizaris of the region was raising funds to build a memorial to the legendary preacher Nasir Khusrav ${ }^{77}$.

The main events of August and November 1991 that led to the birth of the Autonomous Republic of Badakhshan, took place outside the Pamir Mountains.

Within the framework of institutionalizing of non-governmental organizations in 1991 in the Ministry of Justice, there was registered an organization "La'li Badakhshon" (Lal of Badakhshan). A PhD in Mathematics and a professor of Pedagogical institute from Dushanbe, Atobek Amirbekov, became its leader, with members being students and the youth of Dushanbe. In line with its Statutes, "La'li Badakhshon" intended to actively aid the "development of political thinking, economics, culture and education of the peoples of Badakhshan"78. In practice, the organization appeared to adhere to general democratic ideas, and promoted creation of a Pamir cultural centre in Dushanbe. According to the data collected by M.M. Khudoerov, the basic cells of the organization existed in Khorugh and outside GBAO - in Nurak, Qurghonteppe and Yovon, where Pamir immigrants lived. The total number of the members of the organization amounted to 500 people $^{79}$, although in the Pamir Mountains themselves the activity of the organization only became visible in the course of the December events.

The 1991 Soviet coup detat attempt, or the "August Putsch" and declaration of independence of the republic of Tajikistan followed by the September conflict in Dushanbe, did not affect GBAO, according to the evidence that we acquired. That noted, involvement of the Pamirs into the capital conflicts, sooner or later, had to bring up the question of which of the new political fractions Badakhshan was going to be with.

Most of urbanized intelligentsia apparently believed that fast-track reforms would enable to overcome the socio-political, economic and cultural discriminations that were considered to hinder development of the Soviet Badakhshan. In pursuit of immediate and tangible results, the intelligentsia, most of whom lived outside GBAO, supported "democrats" that laid their hands on the power in a number of republics, and radical supporters of reforms in the whole of Tajikistan ,such as "Rastokhez", "demo-Islamites", the Democratic Party of Tajikistan. Paradoxically, at the Soviet and republican levels, the democrats supported the side of protagonists of "national" and religious resurrection of the dominant ethnic group. Success in achieving the above-mentioned goals would have automatically left the Pamirs face to face with the nationalist and Sunni Centre, while being deprived of the habitual possibilities of using the Party to de-escalate the situation and appealing to the all-Soviet actors. Probably, this is the reason why GBAO, at first, distanced itself from

77 Hodzhibekov Je. H. Istoriia aktivizacii religii i religioznyh deiatelei GBAO Respubliki Tadzhikistan v gody Perestroiki (1985-1991 gg.) // Uspehi sovremennoi nauki. 2017. Vol. 4, iss. 2. P. 179-180.

78 Prilozhenie N 7: Ustav organizacii "Lali Badahshon" // Hudoerov M. M. Social'no-politicheskie i etnokul'turnye transformacii na postsovetskom Pamire. Diss. ... kand. ist. nauk. Moscow, 2012. P. 244-225.

${ }^{79}$ Hudoerov M. M. Social'no-politicheskie i etnokul'turnye transformacii... P. 54. 
all republican conflicts. That situation, however, could not last for long. Old mechanisms of communication with Dushanbe were disappearing. For instance, in October, by the decision of the Supreme Soviet of the Republic of Tajikistan the activities of the Communist party were suspended ${ }^{80}$. A. Sobchak and E. Velikhanov, who came from Moscow, supported the "democratic" opposition. At the same time, in the conditions of a permanent crisis, decision-making process on all the issues that were vital for GBAO and were previously made by the Supreme Soviet, were also suspended. In this chaos, the people of the Pamirs needed a new hero, who could listen to their voices, who was highly - unofficially - esteemed, and, at the same time, who could assume power. The only candidate for the role was a famous Soviet film director Davlat Khudonazarov.

The cultural luminary from Khorugh was a people's deputy from Shughnan at the top level of the USSR in 1989-1991. In Moscow, he proved to be a supporter of the "democratic opposition", so when the $5^{\text {th }}$ session of People's Deputies ended at the beginning of September, he came back to his motherland glorified as a reformer and someone who fought party nomenclature. It is no wonder, then, that at presidential elections in Tajikistan, in November 1991 D. Khudonazarov was made a nominee, formally from the "Democratic party of Tajikistan". Obviously, the Pamiris were, from the beginning, inclined to support their famous and progressive fellow countryman. His popularity was also based on the information, provided by the press and orally, about his personal participation in humanitarian supplies to GBAO, and lobbying in Moscow the continuation of construction of hydroelectric power station "Pamir-1"81, connections with B. N Yeltsin, M.S. Gorbachev, English scientists and American congressmen ${ }^{82}$. During the first three weeks of November 1991, the main Pamir newspaper "Soviet Badakhshan" published eight articles, which campaigned for D. Khudonazarov in different forms, whereas out of all the other candidates only A. N. Maksumov published his biography and his election agenda in this press title ${ }^{83}$. "Kinovideoobyedineniye" of GBAO held a mini-festival of D. Khudonazarov's films ${ }^{84}$. Finally, the famous countryman was the only candidate who visited GBAO during the electoral campaign and held a meeting with electorate in the city stadium of Khorugh $^{85}$. It is, therefore, hardly surprising that at least $90 \%$ of the electorate of GBAO voted for him on 24, November, 1991.

Nevertheless, the election ended in his failure, since he gathered in the country as a whole $30,07 \%$ votes. In the end, the former First Secretary of the Central committee of the TSSR Communist party, resident of Leninabad R. N. Nabiev became the President ${ }^{86}$. The disheartening proof of the inability of citizens of GBAO to influence the situation in the whole country led to an eruption.

${ }^{80}$ Mozhno priostanovit' deiatel'nost' partii, no ne politicheskuiu zhizn' liudei // Badahshoni Soveti. 1991. 11 noiabria. P. 4.

${ }^{81}$ Karamshoev D. Davlat - redkaia lichnost' sovremennosti // Badahshoni Soveti. 1991. 20 noiabria. P. 4 .

${ }^{82}$ Kaplunov Ju. O Davlate Hudonazarove // Badahshoni Soveti. 1991. 20 noiabria. P.4; Protokol N 6 sessijai shashumi (davati bistujakumi) Shuroi deputathoi halki vilojati muhtori Kuhistoni Badahshon // GA GBAO. F. 1. Op. 49. D. 5. L. 7-8).

83 A. N. Maksumov - kandidat v prezidenty Respubliki Tadzhikistan // Badahshoni Soveti. 1991. 16 noiabria. P. 4.

${ }^{84}$ Lutfasanov K. Na ekrane - fil'my kandidata // Badahshoni Soveti. 1991. 22 noiabria. P.4.

${ }^{85}$ K vyboram prezidenta respubliki // Badahshoni Soveti. 22 noiabria. P. 4.

${ }^{86}$ Intihobi prezidenti chumhurii Tochikiston // Badahshoni Soveti. 1991. 27 noiabria. P.1. 
On 3 December a mass protest began in Khorugh on the main square named after V. I.Lenin. The action was initiated (according to the information from the local press) by the Shughnan youth ${ }^{87}$. A number of political demands were voiced at the meeting: an unscheduled convention of the Soviet of People's deputies of GBAO, "transfer from the status of autonomous region to autonomous republic", introduction of the post of President of the region and re-election of Chairmen of the city administration of Khorugh and the regional Soviet of People's deputies by "nation-wide voting", recall and re-election of representatives of GBAO in the Supreme Soviet of Tajikistan, regional and city Soviets. Apart from that, there were also some "enforcement" demands: to publish information about the demands in the press, to "invite" members of the organizing committee of the meeting to the session of the regional Soviet and not to hold the participants of the meeting lia$\mathrm{ble}^{88}$. In essence, as it was acknowledged by coordinators of the meeting, F. Mirasanov and U. Abdolbekov, the case was sovereignization of Badakhshan within Tajikistan, by analogy with a number of parallel cases on the post-Soviet area ${ }^{89}$. At the same time, as much as we can make of a whole number of lapsus linguae that can be found, for instance, in the speech made at Lenin square for "all the people of GBAO" published on 6 December, the actual political views of the protesters were largely limited to the regional capital and the Shughnan district ${ }^{90}$. We daresay that this increasing tendency of the Badakhshan sovereignization towards Shughnan later on became one of the reasons for its failure.

People's deputies of GBAO immediately started to negotiate with the protestors, and the conversations ended in creation of a special commission of the regional Soviet on 4 December, which was to deal with the question. However, the activists did not intend to leave the central square of the Pamir capital until all their demands were met: first of all, an immediate holding of the session of the Soviet (given that the next session was scheduled for 20 December). Despite winter, the number of participants grew. They were joined by trade unions and representatives of a number of the regional districts. A. Amirbekov, the Chairman of "La'li Badakhshan", came from Dushanbe in order to support the protesters. An interview with the visiting zealot of the Pamirs' freedom and prospects was published under a telling heading "What is "La'li Badakhshan" anyway?" 1 . Nevertheless, the 1800 roubles donated by the society became a tangible sign of the support of the events in GBAO by the "democratic" powers in the country. People's deputies had to take a step back.

The unscheduled session of the Soviet of People's deputies of GBAO that took place on 9 December was held, due to its extraordinary nature, with an unusual composition of people present. There were, according to the meeting's minutes, representatives of the organizing committee of the protesters, Atobek Amirbekov - the leader of La'li Badakhshon, and deputies of the Supreme Soviet of Tajikistan - Sh. Shabdolov, M. Nazarshoev, E. I. Turgunov, B. Tashtanov and the Minister of Internal Affairs of Tajikistan M. Navdzhuvonov $^{92}$. Despite the very impressive entry list, the discussion of proclaiming GBAO

${ }^{87}$ Kurbonbekov Sh. Girdixamoi dar majdoni Lenin // Badahshoni Soveti. 1991. 5 dekabria. P. 1.

${ }_{88}$ Habib L. Verim, stoim, trebuem // Badahshoni Soveti. 1991. 6 dekabria. P. 4.

89 Suverenitet v ramkah Tadzhikistana // Badahshoni Soveti. 1991. 10 dekabria. P. 1.

90 Obrashhenie mitinguiushhih na ploshhadi im. V.I.Lenina goroda Horoga ko vsem zhiteliam GBAO // Badahshoni Soveti. 1991. 6 dekabria. P. 4.

${ }^{91}$ Habib L. Chto za "Lali Badahshon" // Badahshoni Soveti. 1991. 18 dekabria. P. 4.

92 Protokol N 6 sessijai shashumi (davati bistujakumi) Shuroi deputathoi halki vilojati muhtori Kuhistoni Badahshon. L. 1, 15. 
a republic, as much as we can judge from the documents, did not as such take place. Most of people's deputies of the regional Soviet were, together with a representative of the meeting at Lenin square, F. Khonibekov, unanimous when it came to uneven distribution of resources in favor of Leninabad region and Dushanbe, crisis of transport infrastructure, construction and educational system in the region. They saw the problem in promoting the status of GBAO and receiving full control over the local natural resources. The hopes for concluding agreements for cooperation and creating joint ventures with other post-Soviet republics, China and Afghanistan, shared by the people's deputies, were quite typical, as well as the myths about the "majority of republics that enhanced their economies and overcame the crisis", and that it was only the lack of the status of republic that hindered the development of the Pamirs ${ }^{93}$. Representatives of GBAO in the Supreme Soviet of Tajikistan were criticized for their "half-heartedness".

Only 2 out of 19 speeches were of a different, non-enthusiastic nature. One of them was a short oration made by the Chairman of the Soviet of Murghab district, S. Abdyrakhmanova, who brought to light the informational isolation of the biggest locality of Badakhshan. She only found out about the demands made by the protestors when she came to Khorugh. The language barrier had almost excluded the Kirghiz population from the regional political process. Apart from that, the Murghab deputy warned about the consequences of cessation of fuel deliveries from Tajikistan when the temperatures were below 40 degrees Celsius in the winter ${ }^{94}$.

Sh. D. Shabdolov, Chairman of the Communist party of the Republic of Tajikistan, was no less skeptical. He expressed doubt in expediency of recalling deputies from Dushanbe and confrontation with the central power, and made a justified surmise that "no republic of the Union wants to deal with us without the Republic [of Tajikistan. - A. D., A.A., V.Sh.]"95. In a private conversation 27 years later Shodi Davlatovich recalled that he warned the creators of the Autonomous republic of Badakhshan that approval of it at the level of the Supreme Soviet of the Republic of Tajikistan was unfeasible ${ }^{96}$.

Eventually, the Soviet of People's deputies of GBAO arrived at resolution N 99. According to this document, the Mountain Badakhshan Autonomous region was transformed into the Autonomous Republic of Badakhshan as part of Tajikistan. Moreover, the document stipulated that the Supreme Soviet should be asked to approve the resolution made, and address all governmental structures of the Republic of Tajikistan asking to support the resolution. There was also created a commission for development of the newly created constitution of the republic ${ }^{97}$. After the provisions of the new document were satisfied, the deputies headed by the Chairman of the regional Soviet A. Iskandarov listened to a grateful speech of the representative of protestors, F. Mirasanov, and went to Lenin square, where the celebration of a victory so long anticipated began... ${ }^{98}$

The events which followed demonstrated that the plans of ethno-political consolidation of Mountain Badakhshan were unrealizable. The region, despite the crisis of supply and utility systems, and disintegration of the all-Union distribution system, had been de-

93 Ibid. L. 1-11.

94 Ibid. L. 11-12.

95 Ibid. L. 14.

96 From the private conversation between the authors of this paper and Sh. D. Shabdolov (6.02.2018).

97 Protokol N 6 sessijai shashumi (davati bistujakumi) Shuroi deputathoi halki vilojati muhtori Kuhistoni Badahshon. L. 16.

98 Habib L. GBAO - avtonomnaia respublika // Badahshoni Soveti. 1991. 11 dekabria. P. 4. 
pendent on the republican Centre since the 1920s. The ethno-confessional Isma'ili factor could not prove to be a sufficient basis for an all-Pamir integrated identity. Dissection of the system of political processes in the Pamir region in 1989-1991 shows the futility of the sovereignization project in the region due to a whole range of reasons. Among them we can point out the absence of solidarity among representatives of the "old" party nomenclature concerning both the law "On GBAO" and the declaration of independence of Badakhshan; economic dependency on the USSR Centre, passiveness of ethnic Pamiri who held positions in central government of Tajikistan. Among external factors, the "hot breath" of Afghanistan and lack of support from the "democratic forces" of the Russian Soviet Federative Socialist Republic should be singled out. For example, the visit to Dushanbe of A. A. Sobchak and E. P. Velikhov in September 1991 took place only in order to reconcile the "democratic Islamists" with the official powers. Only very few people attached importance to the declaration of Badakhshan independence against the background of the growing civil conflict.

\section{References}

Akimbekov S. M. Istoriia Afganistana. Astana; Almaty, IMJeP pri Fonde Pervogo prezidenta Publ., 2015, 848 p. (In Russian)

Artykbaev A. M. Ferganskii klaster: istoriia i sovremennost'. Obozrevatel', 2014, vol.2, pp. 83-90. (In Russian).

Brasher R. Ethnic Brother or Artificial Namesake? The Construction of Tajik Identity in Afghanistan and Tajikistan. Berkeley Journal of Sociology, 2011, vol. 55, pp. 97-120.

Boldyrev V. A. Itogi perepisi naseleniia SSSR. Moscow, Finansy i statistika Publ., 1990, 84 p. (In Russian)

Bozorov K. D. Pereselencheskaia politika pravitel'stva Respubliki Tadzhikistan v poslevoennyi period $i$ ee social'no-ekonomicheskoe i kul'turno-bytovoe znachenie, 1946-1965 gg. Thesis of Kand. Diss. (in History). Dushanbe, 2002, 22 p. (In Russian)

Bushkov V.I., Mikul'skii D. V. Anatomiia grazhdanskoi voiny $v$ Tadzhikistane (etnosocial'nye processy i politicheskaia bor'ba, 1992-1995). Moscow, Institut prakticheskogo vostokovedeniia RAN Publ., 1996, 169 p. (In Russian)

Bushkov V., Monogarova L. Etnicheskie processy v Gorno-Badahshanskoi avtonomnoi oblasti Tadzhikistana. Central'naia Aziia i Kavkaz, 2000, iss. 5, pp. 215-233. (In Russian)

Cheshko S. V. Vremia stirat' belye piatna. Sovetskaia etnografiia, 1988, iss. 6, pp. 5-6. (In Russian)

Cheshko S. V. Raspad Sovetskogo Sojuza. Etnopoliticheskii analiz. $2^{\text {nd }}$ ed., Moscow, IJeA RAN Publ., 2000, 398 p. (In Russian)

Davydov A. S. Ne obosnovanno... zato publicistichno. Sovetskaia etnografiia, 1989, iss. 5, pp. 15-23. (In Russian)

Dodihudoev R. Dokole budem slyt' mankurtami. Kommunist Tadzhikistana, 1989, iss. 5, pp. 28-29. (In Russian)

Dodihudoev R. H. Iazykovaia politika i iazykovoe stroitel'stvo v Tadzhikistane. Russkii iazyk v SSSR, 1991, no. 9, pp. 5-7. (In Russian)

Griunberg A.L., Steblin-Kamenskij I. M. Neskol'ko zamechanii po povodu otklika A.S. Davydova na stat'iu S. V.Cheshko. Sovetskaia etnografiia, 1989, iss. 5, p. 35-38. (In Russian)

Gvozdeckii N. A., Mihailov N. I. Fizicheskaia geografiia SSSR. Aziatskaia chast'. Moscow, Mysl' Publ., 1978, 512 p. (In Russian)

Hodzhibekov Je. H. Istoriia aktivizacii religii i religioznyh deiatelei GBAO Respubliki Tadzhikistan v gody Perestroiki (1985-1991 gg.). Uspehi sovremennoi nauki, 2017, vol. 4, iss. 2, pp. 179-180. (In Russian)

Honaliev N. GBAO - problemy social'no-ekonomicheskogo razvitiia. Central'naia Aziia i Kavkaz, 2004, vol.31, iss. 1, pp. 186-195. (In Russian)

Hudoerov M. M. Problema Pamirskoi avtonomii v Tadzhikistane na rubezhe 1980-1990-h gg. Vestnik of Cheliabinsk State University, 2011, vol.237, iss.22, pp.78-81. (In Russian)

Hudoerov M. M. Social'no-politicheskie i etnokul'turnye transformacii na postsovetskom Pamire. Diss. ... kand. ist. nauk. Moscow, 2012, 225 p. (In Russian) 
Malashenko A. V. Tadzhikistan: dolgoe eho grazhdanskoi voiny. Brifing Centra Karnegi, 2012, vol. 14, iss. 3, 12 p. (In Russian)

Mandelbaum M.H. The Anatomy of Historical Knowledge. Baltimore; London, Johns Hopkins University Press, 1979, $230 \mathrm{p}$.

Monogarova L.F. Etnicheskii sostav i etnicheskie processy v Gorno-Badahshanskoi avtonomnoi oblasti Tadzhikskoi SSR. Strany i narody Vostoka, 1975, iss. 16, pp. 174-191. (In Russian)

Monogarova L.F. Pamircy - narodnosti ili subetnosy tadzhikov? (otvet A. S. Davydovu). Sovetskaja etnografiia, 1989, issue 5, pp. 28-34. (In Russian)

Nourzhanov K., Bleuer K. Tajikistan: a Political and Social History. Canberra, ANU E Press, 2013, 420 p.

Ovsiannikov D. V., Hasanov A. R., Ianchenko D. G. Problema transformacii statusa nacional'nyh iazykov narodov SSSR na primere sovetskogo i postsovetskogo Tadzhikistana v 1980-2010-e gg. Obshhestvo. Sreda. Razvitie, 2015, iss. 4, pp.91-99. (In Russian)

Pahalina T.N. Osnovy iranskogo iazykoznaniia: sredneiranskie i novoiranskie iazyki. Moscow, Vostochnaia literatura, 2008, pp. 103-113. (In Russian)

Pahalina T. N. Pamirskie iazyki. Moscow, Nauka Publ., 1969, 163 p. (In Russian)

Parshin P. B. Mesto i rol' Gorno-Badahshanskoi Avtonomnoi oblasti v Gosudarstvennoi sisteme Tadzhikistana. Mezhdunarodnaia analitika, 2016, vol. 16, iss. 2, pp. 83-96. (In Russian)

Postnikov A. V. Shvatka na "kryshe mira": politiki, razvedchiki i geografy v bor'be za Pamir v XIX veke (monografiia $v$ dokumentah). Ed. by V.S. Miasnikov. Moscow, Pamiatniki istoricheskoi mysli Publ., 2001, 416 p. (In Russian)

Radzhabov S., Bobodzhanov N. Sovetskii Badahshan v bratskoi seme narodov SSSR. Dushanbe, Irfon Publ., 1975, 36 p. (In Russian)

Rashid A. The Resurgence of Central Asia: Islam or Nationalism. London, Oxford University Press, 1994, $288 \mathrm{p}$.

Rowland R.H. National and Regional Population Trends in Tajikistan. Results from the Recent Census. Eurasian Geography and Economics, 2005, vol. 46, no. 3, pp. 202-223.

Sergeev E. Ju. Bol'shaia igra, 1856-1907: mify i realii rossiisko-britanskih otnoshenii v Central'noi $i$ Vostochnoi Azii. Moscow, Tovarishhestvo nauchnyh izdanii KMK Publ., 2012, 454 p. (In Russian)

Shahraj S. M. Mify i fakty o raspade Soiuza SSR. Raspad SSSR: Dokumenty i fakty (1986-1992 gg.), Vol.II. Arhivnye dokumenty i materialy. Ed. by S. M. Shahraj. Moscow, Kuchkovo pole Publ., 2016, 824 p. (In Russian)

Sharafieva O.H. Rol' regional'nyh klanov vo vnutrennei politike Tadzhikistana. Vestnik of Tomsk State University, 2012, vol.359, pp.98-100. (In Russian)

Sitnianskii G. Ju. Rossiia i Central'naia Aziia: vmeste ili vroz'? Mezhetnicheskie otnosheniia v Srednei Azii i Kazahstane i Rossiia, Moscow, IJeA RAN Publ., 2011, 290 p. (In Russian)

Tereshhenko V.V. Samaia effektivnaia okruzhnaia pogranichnaia sistema (1960-1990 gg.). Vestnik of Tomsk State University. Gumanitarnye nauki. Istoriia i politologia, 2013, vol.121, iss.5, pp.226-234. (In Russian)

Umarov H. U., Muhabbatov H.M., Akobirov Sh.Z. Piandzhskii transgranichnyi bassein: resursy i problemy social'no-ekonomicheskogo razvitiia. Izvestiia RAN. Seriia Geograficheskaia, 2014, iss. 6, pp. 101-109. (In Russian)

Received: 24.04 .2018

Accepted: 31.05 .2018 